The research program of the Center for Economic Studies (CES) produces a wide range of theoretical and empirical economic analyses that serve to improve the statistical programs of the U.S. Bureau of the Census. Many of these analyses take the form of CES research papers. The papers are intended to make the results of CES research available to economists and other interested parties in order to encourage discussion and obtain suggestions for revision before publication. The papers are unofficial and have not undergone the review accorded official Census Bureau publications. The opinions and conclusions expressed in the papers are those of the authors and do not necessarily represent those of the U.S. Bureau of the Census. Republication in whole or part must be cleared with the authors.

\title{
CIVIC COMMUNITY IN SMALL-TOWN AMERICA: HOW CIVIC WELFARE IS INFLUENCED BY LOCAL CAPITALISM AND CIVIC ENGAGEMENT
}

by

\author{
Charles M. Tolbert* \\ Baylor University
}

Michael D. Irwin*

Duquesne University

Thomas A. Lyson*

Cornell University

and

\author{
Alfred R. Nucci * \\ U.S. Census Bureau
}

CES 01-19 December, 2001

All papers are screened to ensure that they do not disclose confidential information. Persons who wish to obtain a copy of the paper, submit comments about the paper, or obtain general information about the series should contact Sang V. Nguyen, Editor, Discussion Papers, Center for Economic Studies, Washington Plaza II, Room 206, Bureau of the Census, Washington, DC 20233-6300, (301-457-1882) or INTERNET address snguyen@ces.census.gov. 
The aims of this paper are twofold: first, to gain a fuller understanding of factors that foster community cohesion and contribute to the residents' social and economic well-being; and, second, to move beyond previous research that used larger spatial units such as states, counties, or aggregates of counties and to focus instead on American small towns (population 2, 500-20,000). The data on small towns are drawn from public-use files and from confidential microdata from various economic censuses. From these sources we construct measures of locally oriented firms, selfemployment, business establishments that serve as gathering places, and associations. The local capitalism and civic engagement variables generally perform as hypothesized; in some cases they are related quite strongly to civic welfare outcomes such as income levels, poverty rates, and nonmigration rates. We discuss the advantages and disadvantages of working with placelevel data and suggest some strategies for subsequent work on small towns and other incorporated places.

* This material is based on work supported by the Cooperative State Research, Education, and Extension Service, U.S. Department of Agriculture, under Agreement 98-35401-6555. The research in this paper was conducted while the authors were Census Bureau research associates at the Center for Economic Studies. Results and conclusions expressed are those of the authors and do not necessarily reflect agreement by the Bureau of the Census. This paper has been screened to ensure that no confidential data are revealed. An earlier version was presented at the 1999 annual meeting of the Rural Sociological Society, held in Chicago. Thanks to Troy Blanchard and the anonymous reviewers for helpful commentary. Direct correspondence to the first author at the Department of Sociology and Anthropology, Baylor University, Waco, TX 76798; charlie_tolbert@baylor.edu 
In describing social conditions in the United States shortly after the Revolutionary War, Alexis de Tocqueville declared: "Municipal institutions constitute the strength of free nations" (1994:61). In the small towns across America, he found that the foundation of civil society rested on the constellation of small shop owners, public forums, and the citizens' propensity to interact. The institutional foundation for public good was anchored in the American system of townships. Tocqueville also warned, however, that such civic townships were easily destroyed by "the constant action of the laws and the national habits, peculiar circumstances, and above all, time" (1994:61).

Today, when advanced telecommunications, mass-market retailers, and global commodity chains are creating a worldwide system of production and consumption, it may seem that the institutional basis for civic community in small-town America is dissolving rapidly. Yet a more contemporary line of social science research, dating back to C. Wright Mills (Mills and Ulmer 1946) and Walter Goldschmidt (1946) and amplified by Lyson and Tolbert (1996), Tolbert, Lyson, and Irwin (1998), and Irwin, Tolbert, and Lyson (1999), suggests that Tocqueville's constellation of small, locally oriented institutions and the associated civic engagement indeed builds the local "common weal."

If Tocqueville's configuration of local institutions, involved citizens, and community spirit survives anywhere, it is most likely to be found in the American small town. "The township institutions...form a complete and regular whole; they are old; they have the support of the laws and the still stronger support of the manners of the community, over which they exert a prodigious influence. For all these reasons they deserve our special attention" (Tocqueville 1994:61). Two hundred years later, Putnam (2000:205) expressed a similar idea: "Getting involved in community affairs is more inviting—or abstention less attractive—when the scale of everyday life is smaller and more intimate." Following Tocqueville's classic injunction and Putnam's contemporary observation, we focus here on small towns.

In small-town America, we theorize that civic engagement is enmeshed in locally oriented businesses and a constellation of local associations and organizations. A community's social and 
economic institutional matrix not only fosters a sense of public integration and cohesion but also enhances development of public goods and civic welfare. One aim of this paper is to gain a fuller understanding of factors that foster community cohesion and contribute to the residents' social and economic well-being.

A second objective is to move beyond previous research that used larger spatial units such as states, counties, or aggregates of counties and to focus instead on American small towns. Broader spatial units such as counties or labor markets can encompass a variety of distinct communities and uninhabited spaces. Aggregating social and economic patterns across these areas may mask essential differences in local communities' institutional structures. Certainly community boundaries are not coterminous with the political limits of cities and towns. Yet towns and cities are the institutional centers for these broader communities, and we should find the heart of a civic nexus within city boundaries. We focus on two specific aspects of a municipality's civic institutional structure-local capitalism and civic engagement — and examine the degree to which these factors enhance small towns' civic welfare.

\section{Civic Welfare, Local Capitalism, and Civic Engagement}

Contemporary variants of the civic community perspective can be found in Putnam's $(1993,2000)$ civic engagement thesis, in the work of Etzioni (1996) and other writers in the communitarian tradition, and in the flexible production theory of institutionalists Piore and Sabel (1984). Unlike earlier developmentalist perspectives, which tended to view economic life and social life as relatively distinct, the newly emerging civic community approach focuses on the relationships between economic and noneconomic institutions. The civic community perspective maintains that locally oriented capitalism and civic engagement are the foundations of civic institutions that nurture trust and cooperation among citizens. This contributes to a vital capacity to solve problems and resolve local issues. Workers and owners/managers alike become embedded in localities and make decisions that benefit the community as 
well as themselves. Some of the beneficial local outcomes of community problem solving are evident in local civic welfare. Simply stated, a climate in which civic community thrives is thought to enhance the local residents' well-being.

\section{Civic Community and Local Capitalism}

Locally oriented production firms are likely to contribute to the civic culture because the owners and managers are socially and financially invested in the community (Mills and Ulmer 1946; Piore and Sabel 1984). In part, this local orientation is due to aspects of organizational form associated with size. Small firms usually have less formalized bureaucratic structures and lack the high degree of specialization and compartmentalization associated with their larger, Fordist counterparts (Edwards 1979). A small number of employees precludes a complex division of labor and allows—even requires—informality and mixing of roles. Owners and managers mix and work freely with production workers, creating bridging networks within the workplaces. Without rationalized rules for hiring, new employees often are found through kinship and friendship ties; these practices are advantageous to local residents and maintain employment opportunities for the community.

Further, owners and managers of small firms frequently are active participants in the community's civic affairs. In the various service and business clubs, organizations, and associations, small businesspeople establish and maintain networks of local contacts and supporters (Mills and Ulmer 1946). Because they are citizens of the community, they develop strong local ties to place. As a result of their strong and enduring community ties, they may be less likely to pull out of the community during an economic downturn, and more likely to support and lead local nonprofit institutions.

A local orientation is particularly instrumental for the self-employed. For many of these

individuals, job and firm are coterminous, and the lines between ownership and employment are blurred. Often the decision to shift from wage work to self-employment is motivated by pressures to leave the 
local community. Self-employment becomes a mechanism for maintaining and strengthening ties to place; thus it represents a strong form of local orientation.

Local orientation, however, is not the only reason why small producers are likely to remain in a community. Small business owners and the self-employed rely on one another for support and information. These networks allow small producers to capture economies of scale that enable them to compete effectively with larger firms (Piore and Sabel 1984). Networks of small businesspersons are "place-based" and not readily transferable to other communities; small producers remain tied to locality. Because the networks themselves are embedded in local community institutions, they maintain and strengthen shared values and local community identity.

The industrial sector with the greatest primacy in economic development is manufacturing. It is well established that a manufacturing presence in the local economy is associated with higher wages and lower unemployment (Falk and Lyson 1989; Horan and Tolbert 1984). Most of the contemporary discourse on smaller manufacturing enterprises has centered on small-scale firms and their role in the renaissance of depressed regions and communities (Harrison 1992; Piore and Sabel 1984; Sabel 1989). Size may well be a corollary to local capitalism, but it is only one of several dimensions that define a locally oriented business - that is, a production enterprise that is focused on a local market and customer base. A local business orientation implies that both production and consumption will be focused on the particular socioeconomic and cultural characteristics of that locale. Although this may not be the case for all manufacturing establishments, it is likely that certain products are manufactured largely for local or regional consumption, such as food, apparel, furniture, printing, and publishing.

A civic community perspective suggests that a firm's geographic scope has important implications for local orientation. A multi-establishment firm whose branch plants are scattered across the nation is tied less closely to the conditions and fortunes of any one community. Machinery within plants, and the plants themselves, are moved easily from one community to another in the face of 
declining local economies. Internal labor markets for managers and workers are national and international in scope; residential movement across communities is required for promotion. As a result, managers and owners tend to be oriented primarily to the corporation, not to the community. In contrast, single-establishment firms, as well as multi-establishment firms with all branch plants situated in the local area, are rooted more firmly in place. The ability to move capital out of the community is moderated (although not curtailed); internal labor markets are coterminous with geographic labor markets.

Although the size and the geographic scope of a firm tend to covary, these dimensions are conceptually independent. Similarly, a firm's longevity in an area indicates a dimension of local orientation that is conceptually distinct from both size and scope. Attachment and integration into community structure require time, no less for firms than for individuals.

Size, scope, and longevity, three aspects of local orientation in manufacturing, may create an economic foundation that enhances both the metropolitan and the nonmetropolitan community. In addition, family-owned and controlled farms represent such a local orientation in nonmetropolitan economies and communities. This form of farm ownership is locally oriented in much the same manner as small businesses. Like firms with exclusively local establishments, most family farms are culturally and economically immersed in the community. Families whose economic interests are tied to the farm are much like other local business owners for whom community and economy are intertwined.

A civic community approach suggests that prosperous communities will contain a relatively large number of locally oriented establishments. Such establishments reinforce civic community by building horizontal relationships among residents to which they are linked. These ties, in turn, form bridges across various sectors of the local economy, binding persons and business establishments to the place. In the analysis that follows, we introduce measures of local orientation that reflect a healthy climate of local capitalism. 


\section{Civic Community and Civic Engagement}

In both sociology and political science we find a long-standing interest in the links between voluntary associations and civic engagement. Putnam's (1993) work suggests the possibility of a relationship between local capitalism, levels of local civic engagement, and civic welfare (beneficial local outcomes). Specifically, Putnam suggests that community institutional structures have cross-sectional differences which create varying levels of civic engagement across locales and generate differences in local levels of civic welfare. The proliferation of associations is a central dimension of a civic institutional structure. Simply stated, civic welfare should increase where there are more organizations that encourage association and are oriented toward the public good. Some organizations (for instance, charitable organizations) are formed specifically to enhance some aspect of the public good. Others, such as the VFW or the YMCA, provide a space for community interaction that bonds members to community. Both types increase community cohesion.

Churches and faith-based organizations provide a basis of association and mobilization for community problem solving. Irwin et al. (1999) show that adherence to church embeds people in communities and increases the proportion of people who stay in a community. Similarly, Greeley (1997) finds that religious structures are an important source of volunteerism in church-related and secular activities.

Like churches and associations, local hangouts and gathering places can be an important institutional mechanism for linking individuals together in a community. Oldenburg (1991) notes that "third places," such as pubs, drugstores, coffee shops, barber shops, and grocery stores, provide an institutional basis for informal public life. These retail and service establishments may create horizontal linkages in a community, which increase civic engagement. In addition, these third places are nexus points in networks of acquaintances throughout the community. Such "weak-tie" networks are critical in 
workers' job search patterns and are part of employers' informal hiring practices (Granovetter 1973). The proliferation of such public gathering places, then, increases the density of network connections throughout the community that tie local business activity to local populations. Where such networks prevail, locals find employment more easily, and local businesses are more likely to hire informally within the community. This concept of third places suggests how business establishments can serve as gathering places and venues for civic interaction and for sustenance of informal job search networks. Third places thus are another key aspect of civic community, tying together the components of civic engagement and local capitalism.

\section{Explaining Local Civic Welfare: Dimensions of a Livable Small Town}

Our previous analyses, conducted at the county level, indicate that small manufacturing, retail shops, service establishments, and family farms are associated with higher county population stability (nonmigration), higher income levels, lower poverty levels, less income inequality, and lower unemployment (Irwin et al. 1999; Tolbert et al. 1998). We contend that where these two central dimensions of civic community (local capitalism and civically engaging institutions) coalesce, civic welfare should be greater. This position gives us our basic model for analyzing civic community and civic welfare in terms of two key components (see Figure 1). Though the overarching conceptual model remains the same, we depart from the earlier work in two important ways: we focus on civic community in small towns, and we use detailed economic census microdata that are not in the public domain.

[Figure 1 about here]

\section{Data Sources}

The data used for the measures of local capitalism are taken from sector-specific censuses of the 1992 Economic Census Program, which includes censuses of agriculture, manufacturers, wholesale and retail 
operations, and selected services. Some of our measures use publicly available economic census data (e.g., on farms and nonemployers). Our measures of local orientation (geographic scope, longevity, and size) and our measures of third places and associations are drawn from individual establishments' responses to censuses of manufacturers and of wholesale, retail, and selected services. We constructed these latter measures as part of our research project at the Bureau of the Census Center for Economic Studies. As authorized research associates of the Center, we have access to these establishment data and to the Census Bureau's business register (the Standard Statistical Establishment List).

\section{Identifying Small Towns for Research}

The literature contains few operational definitions of small towns (for examples, see Fuguitt 1968; Fuguitt, Brown, and Beale 1989; Johansen and Fuguitt 1984). In this paper, we define small towns as incorporated places ranging in population from 2,500 to 20,000. An incorporated place ("small town") satisfies two criteria for inclusion in this analysis: (1) the population of these units must be between 2,500 and 20,000 for the both the 1990 decennial Census of Population and Housing and the 1992 subcounty estimates of the Bureau of the Census, and (2) a qualifying incorporated place must be recognized as such in the 1990 decennial Census geography, the 1992 subcounty estimates geography, and the 1992 Economic Census geography. Entities fitting these criteria are called "small towns" throughout this paper.

In regard to population size, the above operationalization provides a relatively homogeneous set of recognized political units that equate reasonably well to small towns. Even so, certain unavoidable biases exist. Most incorporated places have fewer than 2,500 in population, and thus are excluded from this analysis. ${ }^{1}$ This exclusion is the result of the compromise imposed on us by the use of information from both the 1990 decennial Census and the 1992 Economic Census. (In the latter, incorporated places are recognized only if they have a minimum population of 2,500.) Although our population criterion may 
seem arbitrary, Wilkinson (1991) contends that very small communities do not possess complete institutional structures. Thus they are ill-equipped to meet all the needs of residents, and must depend on nearby, larger communities. The 2,500 population threshold employed here thus increases the likelihood that small towns in the analysis have social infrastructures and built environments sufficiently well developed to serve the local population. Minor civil divisions (MCDs) are excluded from this analysis except where they are coterminous with an incorporated place, even though they often constitute small towns or boroughs. ${ }^{2} \mathrm{We}$ also exclude certain unincorporated pieces of territory recognized by the 1990 decennial Census as census designated places (CDPs). ${ }^{3}$

Using these selection criteria, we identify 4,553 small towns in the 48 contiguous states. We further distinguish between small towns located in nonmetro counties $(n=1,886)$ from those embedded in metro counties $(n=2,667) .{ }^{4}$ Tocqueville's experience with small-town America predated the rise of true metropolitan areas: in his day, small towns were centers of rural life and were distinct from the large urban regions in which many small towns are embedded today. Tocqueville stated explicitly, however, that small-town civic institutions exert an influence on the public good quite independent of the counties, the states, and even the nation in which they are located (1994:69). This suggests that civic institutions should operate and should be identifiable in both metropolitan and nonmetropolitan small towns. To assess the extent of similarities in civic community across small towns, we compare results for metro and nonmetro small towns below.

\section{Modeling Strategy}

To evaluate the role of civic community in producing beneficial local outcomes, we estimate ordinary least squares (OLS) regression models. The units of analysis are small towns: that is, incorporated places meeting the criteria outlined above. Previous county-level analyses showed that civic community variables are associated with certain local socioeconomic outcomes such as higher median income, lower 
poverty rates, lower unemployment rates, and more nonmigration (or population retention). We employ parallel outcomes here, which we measure at the incorporated-place level for each of our small towns. The regressors in the models are a set of control items and a set of civic community variables (see Figure 2).

[Figure 2 about here]

Past county-level work in the civic community tradition relied primarily on spatial-effects models, treating the counties as spatial units that encompass all of the territory under study. In the present case, however, the incorporated small towns are spatial units nested in larger geographic entities (e.g., metropolitan areas, counties, states). The small towns do not exhaust the territory between them; therefore our data do not represent all space in the contiguous states. Moreover, the territory omitted from our analysis is a heterogeneous collection of incorporated places of less than 2,500 population, unincorporated places, countryside outside towns, larger towns with populations over 20,000, and very large urban areas. Because our small-town model, by definition, does not account for this territory and because the omitted spaces vary widely in composition, we have opted not to estimate spatial-effects models. Instead we simply treat the small towns as a fairly homogeneous group of spatial units in OLS models, and we employ control items that measure some aspects of the spatial context in which the small towns exist. We estimate models separately for small towns in nonmetro counties and for small towns in metro counties.

\section{Variable Specification: Small-Town Civic Welfare}

Median income. Following previous county-level work in the civic community tradition, we employ several place-level indicators of beneficial local outcomes, all of which are derived from the 1990 decennial population census (U.S. Bureau of the Census 1992b, 1993). Income was a key variable in previous work at the county level, where median income was associated positively with less highly 
refined measures of local capitalism and civic engagement. Here again we examine 1989 median family income at the incorporated-place ("small-town") level. We expect it to be associated positively with the indicators of civil society. In addition, we expect that our refined measures of local capitalism, based on confidential census microdata on the local orientation of firms, will be associated positively with median income.

Poverty rate. We expect these refined measures of local capitalism to be related negatively to our second indicator of socioeconomic well-being: the 1990 Census poverty rate in the incorporated place (small town). Our previous county-level examinations showed the poverty rate to be associated negatively with the civil society variables; we expect to find this result at the place level as well.

Nonmigration. We include a measure of population stability as a dependent variable. Our previous research showed that civic indicators are associated positively with the retention of individuals over time at the county level. Here we examine the more restricted case of place nonmovers (those who did not change housing units between 1985 and 1990 or who relocated within the same incorporated place).

Unemployment. In addition to these income measures, we examine local unemployment levels. Although it would be preferable to average unemployment over a period of several years, unemployment information for small incorporated places is available only at one relevant point in time, the 1990 Census. Because unemployment tends to fluctuate cyclically, measurement at one time period may lead to some instability in this indicator. Nevertheless, we expect that the local capitalism and civic engagement items will be related negatively to unemployment.

\section{Variable Specification: Local Capitalism}

Nonemployers. The local capitalism items include the number of nonemployers, taken from 1992 Economic Census data (represented as its natural log). As the terminology suggests, nonemployers are 
business operators who report no employees, but are self-employed and derive sales and revenues from businesses. The nonemployer business activity may be the only source of the person's income or may be a supplement to wage and salaried work. In either case, we view this form of micro business activity as one important aspect of a thriving local capitalism. Such behavior is unlikely to exist in a vacuum: instead it is very likely to be underpinned by supportive local institutions and networks of cooperating micro businesses. We expect that some incorporated small towns will be more successful at cultivating nonemployers, and that this aspect of local capitalism will vary from place to place. Where the log of nonemployers is relatively high, we expect beneficial local socioeconomic outcomes.

Locally oriented manufacturing. Empirical analysts in the civic community tradition have focused on small manufacturing establishments, contending that small establishments are more likely to be enmeshed in local or regional networks of cooperative firms (see, e.g., Lyson and Tolbert 1996). Following earlier work, we classify manufacturers as small if they have 19 or fewer employees. Thus one measure of locally oriented manufacturing is expressed as the percentage of all manufacturing establishments that are small. As discussed earlier, establishment size is only one aspect of industrial organization that might facilitate local capitalism as opposed to a more global capitalism. Small establishment size has been preferred as a proxy measure of the role of manufacturing in generating local capitalism because it is the one attribute generally available in published data sources such as County Business Patterns. ${ }^{5}$ Yet it is conceivable that a small manufacturing concern could have little or no local orientation and could behave in ways that do not foster the development of local capitalism.

A key advantage of the economic census microdata is that they permit us to explore both geographic scope and longevity of firms, aspects of local orientation that are not reported in published sources. For this analysis, we include a local/nonlocal classification of establishments by single- or multiunit status. We treat single establishments as local. In addition, we view multi-unit establishments as local if all components of the parent enterprise are located in the same county. Multi-unit establishments 
that are part of far-flung enterprises are deemed nonlocal. Thus, in addition to size, we capture the geographic scope of local orientation as the percentage of all manufacturing establishments that are local (either single-unit or multi-unit, all in same county).

A third aspect of local orientation is longevity, from which we infer embeddedness in the local economy. We assess longevity by employing a proxy for age of the manufacturing establishment. This information is derived by linking economic census records with administrative data found in a national business register known as the Standard Statistical Establishment List (SSEL) (U.S Bureau of the Census 1979). Among the data items in the SSEL is the first year in which a tax return was filed for an establishment in a particular location. We use this information to infer the age of an establishment, and employ a measure that is the percentage of all manufacturing establishments 15 years old or more.

A final manufacturing measure of local orientation combines all three dimensions. This is the percentage of manufacturing establishments that qualify as locally oriented on all three measures: small, single-unit or multilocal, and embedded for at least 15 years. By using this three-way interaction term we can assess the extent to which each of these features operates independently from the other aspects of local orientation.

Family farms. Because of their presumed local orientation, family farms have the potential to contribute to civic community. The Census of Agriculture (U.S. Bureau of the Census 1992a) distinguishes between family farms (proprietorships, partnerships, and family corporations) and corporate farms. Public versions of these data employ a county geography; accordingly we construct a family farm measure for incorporated places that indicates whether the small town is located in a county with an above-average per capita number of family farms. ${ }^{6}$ Most farms are likely not to be contained within the incorporated boundaries of our small towns; therefore this binary measure indicates the extent to which agriculture in the local area surrounding the small town is organized around family farms as 
opposed to corporate farming enterprises. Our civic community variables also reflect the concept of civic engagement; we discuss these measures below.

\section{Variable Specification: Civic Engagement}

Third places. From the confidential microdata in the Census of Services and the Census of Retail Trade, we identify service and retail gathering places in small towns for the 1992 economic census year. We choose only service/retail establishments where the good or service typically is consumed on the premises. $^{7}$

Associations. From the Census of Services confidential microdata, we can identify service and retail gathering places in small towns for the 1992 economic census year. Examples of associations include business associations (e.g., Chamber of Commerce), fraternal organizations, labor unions, civic groups, and neighborhood associations. ${ }^{8}$

Civic denominations. As in the civic community literature, we follow the practice of including information on the percentage of religious adherents who identify with civically engaged denominations (Irwin et al. 1999; Tolbert et al. 1998). This information, however, is available only for counties in the 1990 Census of Churches (Association of Statisticians of American Religious Bodies 1992). Using county-level information, we construct a binary item for small towns, which is coded 1 if the county containing the incorporated small town contains an above- average percentage of civic denomination adherents. ${ }^{9}$ 


\section{Variable Specification: Control Items}

Each of our models includes a set of control variables taken from 1990 census sources. Local levels of human capital are introduced through a "percent high school graduate" variable. We expect that local socioeconomic well-being will be associated positively with local education levels.

Three items describe the town's housing stock: percent owner-occupied units, percent vacant units, and percent housing units occupied for 10 or more years by same persons. These housing items shed light on the growth and stability of the area.

A "percent urban" variable indicates the percentage of the local (county) urban population accounted for by the town. A high percentage suggests that the town accounts for most of the nearby urban population; a low percentage indicates that the town is part of a larger urban system. We also include a relative population measure, which compares the town with all small towns in our data set by forming a ratio of the town's population to the average population of all small towns (mean $=7,414$ persons). This item permits us to control for population size within the 2,500-20,000 range specified for our set of small towns.

Given our interest in the role of manufacturing in generating civic community, we control for the number $(\log )$ of manufacturing establishments in the township. This measure, taken from the 1992 Census of Manufacturers, permits us to assess the contribution of the civic community manufacturing items over and above the relative pervasiveness of manufacturing in the local economy.

Finally, to control for regional effects, we include three census region binary variables (Northeast, Midwest, South), using the West for contrast.

\section{Results}

\section{Descriptive Results}


In Table 1 we compare means and standard deviations on the variables employed in our models for incorporated nonmetro and metro small towns. In regard to statistically significant differences among the outcome measures, metro small towns show higher log median income levels and lower poverty rates. The small towns clearly exhibit the well-known metro/nonmetro income differentials (McGranahan 1980). Unemployment rates and nonmigration rates are higher in nonmetro small towns; these findings also are consistent with previous research. Among the control variables, rates of high school education are higher in metro small towns, as are percentage of owner-occupied housing and relative population. Nonmetro small towns exhibit significantly higher values on the age of housing stock, percent vacant, and percent housing occupied more than 10 years. Not surprisingly, the means for percent urban indicate that nonmetro small towns account for more of the urban population in their counties than do metro places. Finally, the log of manufacturing establishments is higher in nonmetro than in metro small towns.

[Table 1 about here]

Nonmetro and metro incorporated small towns are also compared in terms of civic community measures in Table 1. They exhibit no statistically significant difference in log of nonemployers. Disclosable results for the locally oriented manufacturing items are mixed. Nonmetro small towns contain a higher percentage of manufacturing establishments that have been in the community for at least 15 years; metro small towns contain a higher percentage of small manufacturing establishments. Although we cannot disclose the means, we can report that metro towns contain significantly more local manufacturing establishments than do nonmetro towns. We find no significant difference between metro and nonmetro small towns on the three-way local manufacturing interaction term nor on the family farm item. Among the disclosable civic engagement means, nonmetro small towns are more likely than metro small towns to have above-average concentrations of adherents to civic denominations. We cannot disclose the actual means, but nonmetro small towns also contain more third places and more 
associations. On all three civic engagement measures, then, nonmetro small towns exhibit higher values than metro small towns.

\section{Modeling Results}

OLS estimates of $1990 \log$ median family income and 1990 poverty rate are presented in Table 2. The first column of coefficients for each model contains estimated parameters for 1,886 nonmetro small towns. For brevity, we do not comment here on the control items except to note that they generally perform as expected. We focus instead on the local capitalism and civic engagement measures that are key to our civic community approach.

\section{[Table 2 about here]}

Beginning with the median income estimates in Table 2, we observe a positive association with the presence of nonemployers for both nonmetro and metro small towns. In the metro small-town model, the standardized coefficient for the nonemployer variable is the third highest in the model, suggesting the importance of this form of micro business activity in the metro context. The two types of towns differ, however, in the relation of the local capitalism manufacturing items to median income levels. In regard to the manufacturing measures, the longevity of the establishments is important for income in nonmetro small towns. Net of establishment age, the local orientation and size measures are actually negative. For metro small towns, percent local manufacturing establishments and percent manufacturing establishments 15 years old or more are associated negatively with median income (net of the three-way civic manufacturing measure). For metro small-town income levels, the combination of local orientation, small size, and longevity exerts a different influence than do two of its components (locality and size). The standardized coefficients for the manufacturing measures, however, tend to be relatively small.

Among the civic engagement measures, the log of third places is associated positively with small-town median income levels. Though we cannot disclose the standardized coefficient for third 
places in nonmetro incorporated places, it is one of the highest in the nonmetro income model. Also in the nonmetro model, location in a county with an above-average percentage of civic denomination adherents is associated with higher median income. Contrary to expectations, log of associations is associated negatively with log median income in metro small towns.

The third and fourth columns of Table 2 display coefficients for OLS models predicting 1990 poverty rates in our set of small towns. In nonmetro towns, presence of nonemployers is associated with substantially lower levels of poverty. This local capitalism indicator has the fifth highest standardized coefficient in the nonmetro model. Location in a county with above-average percentages of civic denomination adherents, family farms, and log of third places also is associated negatively with nonmetro small-town poverty levels. Though not disclosable, the third places standardized coefficient indicates that it is related strongly to local poverty levels in nonmetro small towns. Among the metro small-town civic community items, log of nonemployers, percentage of local manufacturing establishments, location in a county with an above-average percentage of civic denomination adherents, and log of third places are associated negatively with poverty levels. As in the median income model, log of associations exhibits a coefficient contrary to our expectations in the metro poverty model. Nonetheless, in the metro small-town case, none of the standardized coefficients is especially large.

Estimates of nonmigration and 1990 unemployment are presented in Table 3. The first four columns of coefficients in this table pertain to OLS models of nonmigration (or population stability of a place). Among the civic community items, percent older (15+ years) manufacturing establishments, small manufacturing establishments, civic denominations, log of third places, and log of associations are associated positively with nonmetro small-town nonmigration levels. Once again, the nondisclosable standardized coefficient for third places is a major factor in the model. This is the only model in which the nonemployers item does not work as expected: it is associated negatively with nonmetro small-town nonmigration. In the metro case, log of nonemployers, location in a county with an above-average 
percentage of family farms, and log of associations are associated positively with small-town median income levels. The nonemployers item is the fourth highest standardized coefficient in the model. The standardized coefficient for the associations measure cannot be disclosed, but its magnitude is nearly that of the nonemployers coefficient.

\section{[Table 3 about here]}

In the two final columns of Table 3, we list coefficients for small-town models of 1990 unemployment. Among the nonmetro civic community items, the log of nonemployers and location in a county with above-average percentages of civic denomination adherents and family farms are associated negatively with small-town unemployment levels. As suggested by the standardized coefficients, the civic denomination and nonemployer items are especially important in explaining variance in nonmetro unemployment. With respect to metro small-town unemployment, we find negative coefficients for log of nonemployers, location in a county with an above-average percentage of civic denomination adherents, and log of third places. The nonemployers item remains prominent in these models with the highest standardized coefficient among the civic items. The remainder of the significant civic community variables display lower standardized coefficients but still contribute to the model. Contrary to our expectations in this model, the log of associations is associated positively with metro unemployment.

\section{Summary of Results}

The civic community items employed here are generally associated with civic welfare, as we would expect. The nonemployer, civic denomination, and third places items perform particularly well in most of the models. Nonemployers and third places are associated with greater civic welfare in models for both metro and nonmetro small towns. The civic denominations measure performs as hypothesized in all nonmetro models and in two of the metro small-town models. 
Net of the other measures of local capitalism and civic engagement, the measures of locally oriented manufacturing perform less well in small towns that we would have thought. We surmise that this may be due in part to our use of a place-level, small-town geography which requires that a plant be physically located within the boundaries of the incorporated place. A manufacturing establishment just outside the city limits or a short drive away would not be represented in our small-town data set. Further research is needed to establish how strongly civic welfare is influenced by locally oriented manufacturing.

The associations item performs as anticipated only in the case of nonmigration. Associations may be another indicator of civic community that is not bounded by the incorporated limits of municipalities.

\section{Conclusions}

Tocqueville would hardly be surprised to observe civic community measures performing as they do here in models for small U.S. towns. More than a century after Tocqueville, Mills and Ulmer (1946) again called attention to the robust character of small to midsize American communities. Building on these seminal works, contemporary researchers in the civic community tradition again are making locality primary in socioeconomic analysis at the expense of larger political structures, which seem increasingly less relevant. It is now clear that the penetration of global capitalism varies from place to place. Some communities have distinctive problem-solving structures; this capacity is fueled by a locally oriented capitalism and civic engagement that engender resilience and resistence to global forces. The results we report suggest that a civic climate anchored in micro-enterprise entrepreneurship, a proliferation of public meeting establishments, and civic denominations is associated with civic welfare.

The civic community perspective has clear implications for local economic policy and community development programs. Communities dominated by one or more large national or multinational firms are vulnerable to greater inequality, lower levels of well-being, and higher rates of 
social disruption than localities where the economy is more diversified. In the current era of economic globalization and political devolution, an effective economic development strategy should be geared toward fostering an economically independent middle class everywhere. Policies to promote and strengthen regional trade associations, local industrial districts, producer cooperatives, and other forms of locally based entrepreneurship should be part of a comprehensive community-based economic development strategy.

Largely because of a dearth of data, place-level analyses are rare in the social sciences. In rural sociology, Fuguitt and colleagues' work on places is the only research of national scope (Fuguitt 1968; Fuguitt, Brown, and Beale 1989; Johansen and Fuguitt 1984). Metropolitan areas, various other county group schemata [PLURAL OF SCHEMA], counties, and county equivalents are far more likely to be employed as spatial units. Yet because small towns more closely encompass the bundle of associations, organizations, and institutions that define communities, it is important to demonstrate the plausibility of place-level analysis. In this instance, a community analysis is made possible by access to confidential establishment microdata that can be aggregated to the place level.

Though we are convinced of the salience and utility of place-level analyses, we note two key drawbacks: absence of suitable spatial modeling techniques and variations among statistical agencies in place definitions. These are important topics for future research.

Findings in this place-level analysis of small towns (as well as those in related literatures) argue for development policies that focus on nurturing a small-business and/or merchant class. Even if smokestack chasing were not already out of vogue, the findings reported here indicate that we should expect little enhancement of civic welfare from a strategy of large-firm development. Indeed, micro enterprises, even those with no employees, appear to generate broadly beneficial development in American small towns. 


\section{References}

Association of Statisticians of American Religious Bodies. 1992. "Churches and Church Membership in the United States 1990." [MRDF]. [CITY?]: Association of Statisticians of American Religious Bodies [producer]. New Haven: Roper Public Opinion Research Center, Yale University [distributor].

Edwards, R. 1979. Contested Terrain. New York: Basic Books.

Etzioni, A. 1996. The New Golden Rule: Community and Morality in a Democratic Society. New York: Basic Books.

Falk, W.W. and T.A. Lyson. 1989. High Tech, Low Tech, No Tech: Recent Occupational and Industrial Changes in the South. Albany: SUNY Press.

Fuguitt, G.V. 1968. "Some Characteristics of Villages in Rural America." Pp. 51-73 in Rural Poverty in the United States, edited by G.L. Wilbur and C. E. Bishop. Washington, DC: U.S. Government Printing Office.

Fuguitt, G.V., D.L. Brown, and C.L. Beale. Rural and Small Town America. New York: Russell Sage.

Goldschmidt, W. 1946. "Small Business and the Community: A Study in the Central Valley of California on the Effects of Scale of Farm Operation". Report of the Special Committee to Study Problems of American Small Business. U.S. Senate, 79th Congress, 2nd session, Committee Print13. Washington, D.C.:U.S. Government Printing Office.

Granovetter, M.S. 1973. “The Strength of Weak Ties.” American Journal of Sociology 78:1360-80.

Greeley, A. 1997. "Coleman Revisited: Religious Structures as a Source of Social Capital." American Behavioral Scientist 40:587-94.

Harrison, B. 1992. "Industrial Districts: Old Wine in New Bottles?" Regional Studies 26:469-83.

Horan, P.M. and C.M. Tolbert. 1984. The Organization of Work in Rural and Urban Labor Markets. Boulder: Westview.

Irwin, M., C.M. Tolbert, and T.L. Lyson. 1999. "There's No Place Like Home: Nonmigration and Civic Engagement." Environment and Planning A 31:2223-38.

Johansen, H.E. and G.V. Fuguitt. 1984. The Changing Rural Village in America: Demographic and Economic Trends Since 1950. Cambridge, MA: Ballinger.

Lyson, T.A. and C.M. Tolbert. 1996. "Small Manufacturing and Nonmetropolitan Socioeconomic WellBeing." Environment and Planning A 28:1779-94.

McGranahan, D.A. 1980. "The Spatial Structure of Income Distribution in Rural Regions." American Sociological Review 45:313-24. 
Mills, C.W. and M.J. Ulmer. 1946. Small Business and Civic Welfare. Washington, DC: U.S. Government Printing Office.

Oldenburg, R. 1991. The Great Good Place. New York: Paragon House.

Piore, M.J. and C.F. Sabel. 1984. The Second Industrial Divide. New York: Basic Books.

Putnam, R.D. 1993. Making Democracy Work: Civic Traditions in Modern Italy. Princeton, NJ:

Princeton University Press.

----. 2000. Bowling Alone: The Collapse and Revival of American Community. New York: Simon and Schuster.

Sabel, C.F. 1989. "Flexible Production and the Re-Emergence of Regional Economies." Pp. 17-70 in Reversing Industrial Decline? Industrial Structure and Policies in Britain and Her Competitors, edited by P. Hirst and J. Zeitlin. Oxford: Berg.

Tocqueville, A. 1994. Democracy in America. Vol. 1. New York: Knopf.

Tolbert, C.M., T.A. Lyson, and M.D. Irwin. 1998. "Local Capitalism, Civic Engagement, and Civic Welfare." Social Forces 77:401-27.

U.S. Bureau of the Census. 1979. The Standard Statistical Establishment List Program. Washington, DC: U.S. Bureau of the Census.

----. 1992a. Census of Agriculture [MRDF]. Washington, DC: U.S. Bureau of the Census [producer and distributor].

----. 1992b. Census of Population and Housing, 1990: Summary Tape File 3 [MRDF]. Washington, DC: U.S. Bureau of the Census [producer and distributor].

----. 1993. Census of Population and Housing, 1990: Summary Tape File 4 [MRDF]. Washington, DC: U.S Bureau of the Census [producer and distributor].

Wilkinson, Kenneth P. 1991. The Community in Rural America. New York: Greenwood. 


\section{Endnotes}

1. See Fuguitt (1968) for an analysis of a sample of incorporated places or "villages" with fewer than 2,500 persons.

2. We made this exclusion because MCDs are recognized in some parts of the country (e.g., New England and certain "strong MCD" states in the Middle Atlantic region and the Midwest) but not in others.

3. The 1992 economic censuses recognize only a small number of CDPs as defined in the 1990 decennial census; those which it does recognize exceed our upper population limit of 20,000.

4. A few places are located in more than one county, and thus yield parts of places associated with each county. In this analysis, we assign a place to a single county based on the part with the largest population.

5. Size information may be suppressed, even in public data sources, to reduce the likelihood that individual establishments could be identified. Suppression for the sake of nondisclosure is common in areas where there are only a few firms or a single, dominant firm.

6. The average per capita number of family farms for counties in the 48 contiguous states is .151 .

7. The SIC codes for third places are retail and service establishments that provide spaces for public interaction and where products are consumed on premises: 5812 (eating places), 5813 (drinking places), 7215 (coin-operated laundries), 7231 (beauty parlors), 7241 (barber shops), 7933 (bowling centers), 7991 (fitness centers), 7992 (public golf courses), 7993 (coin-operated amusement), 7996 (amusement parks), 7997 (sports/recreation clubs), 8231 (libraries), 8412 (museums and art galleries), and 8422 (gardens).

8. The SIC codes employed for associations are 8611 (business associations), 8631 (labor unions), 8641 (civic, social, and fraternal associations), 8651 (political organizations), and 8699 (membership organizations not elsewhere classified).

9. The average proportion of adherents to civic denominations across all counties (48 contiguous U.S. states) is 14.2 percent. An incorporated place is coded 1 on the civic denomination item if the proportion of adherents in the county exceeds 14.2 percent. 
Table 1. Means and Standard Deviations for Metro and Nonmetro Small Towns

\begin{tabular}{|c|c|c|c|}
\hline Variables & $\begin{array}{l}\text { Nonmetro } \\
(n=1,886)\end{array}$ & $\begin{array}{l}\text { Metro } \\
(n=2,667)\end{array}$ & $t$-ratio \\
\hline \multicolumn{4}{|l|}{$\overline{\text { CIVIC WELFARE OUTCOMES }}$} \\
\hline Median family income, 1989 & $\begin{array}{l}26,240.90 \\
(5,541.51)\end{array}$ & $\begin{array}{l}40,222.95 \\
(18,587.28)\end{array}$ & -36.61 \\
\hline Poverty rate, 1989 & $\begin{array}{l}19.33 \\
(9.20)\end{array}$ & $\begin{array}{l}10.14 \\
(8.50)\end{array}$ & 34.26 \\
\hline Nonmigration rate, $1985-1990$ & $\begin{array}{l}71.57 \\
(9.76)\end{array}$ & $\begin{array}{l}64.89 \\
(11.48)\end{array}$ & 21.13 \\
\hline Unemployment, 1990 & $\begin{array}{l}7.72 \\
(3.44)\end{array}$ & $\begin{array}{l}5.73 \\
(3.56)\end{array}$ & 18.95 \\
\hline \multicolumn{4}{|l|}{ CONTROL ITEMS } \\
\hline \% high school graduates, 1990 & $\begin{array}{l}67.84 \\
(10.38)\end{array}$ & $\begin{array}{l}76.81 \\
(12.53)\end{array}$ & 25.5 \\
\hline Age of housing stock, 1990 & $\begin{array}{l}30.75 \\
(9.76)\end{array}$ & $\begin{array}{l}28.21 \\
(12.20)\end{array}$ & -7.49 \\
\hline \% Owner occupied dwellings, 1990 & $\begin{array}{l}64.55 \\
(8.07)\end{array}$ & $\begin{array}{l}68.16 \\
(13.57)\end{array}$ & 11.21 \\
\hline$\%$ Housing vacant, 1990 & $\begin{array}{l}9.25 \\
(9.25)\end{array}$ & $\begin{array}{l}7.01 \\
(7.01)\end{array}$ & -10.94 \\
\hline$\%$ Housing occupied $10+$ years, 1990 & $\begin{array}{l}40.53 \\
(7.74)\end{array}$ & $\begin{array}{l}39.31 \\
(11.34)\end{array}$ & -4.05 \\
\hline Ln manufacturing establishments, 1992 & $\begin{array}{l}2.45 \\
(.80)\end{array}$ & $\begin{array}{l}2.33 \\
(1.04)\end{array}$ & -4.22 \\
\hline$\%$ of urban population in county, 1990 & $\begin{array}{l}.69 \\
(.34)\end{array}$ & $\begin{array}{l}.13 \\
(.22)\end{array}$ & -66.49 \\
\hline Adjacent to metro county, 1990 & $\begin{array}{l}.55 \\
(4.98)\end{array}$ & ----------- & $\mathrm{NA}^{\mathrm{a}}$ \\
\hline Relative populations size, 1990 & $\begin{array}{l}1.00 \\
(.63)\end{array}$ & $\begin{array}{l}1.00 \\
(.58)\end{array}$ & NA \\
\hline Northeast & $\begin{array}{l}.07 \\
(.26)\end{array}$ & $\begin{array}{l}.26 \\
(.44)\end{array}$ & 16.44 \\
\hline Midwest & $\begin{array}{l}.35 \\
(.48)\end{array}$ & $\begin{array}{l}.34 \\
(.47)\end{array}$ & -.72 \\
\hline South & $\begin{array}{l}.44 \\
(.50)\end{array}$ & $\begin{array}{l}.29 \\
(.45)\end{array}$ & -10.23 \\
\hline $\begin{array}{l}\text { CIVIC COMMUNITY ITEMS } \\
\text { Ln nonemployers, } 1992\end{array}$ & $\begin{array}{l}5.54 \\
(.69)\end{array}$ & $\begin{array}{l}5.53 \\
(1.01)\end{array}$ & -.50 \\
\hline \% local manufacturing establishments, 1992 & $-\mathrm{ND}^{\mathrm{b}}$ & $+\mathrm{ND}$ & $\mathrm{S}^{\mathrm{c}}$ \\
\hline
\end{tabular}




$\begin{array}{llll}\text { \% old manufacturing establishments, } 1992 & \begin{array}{l}34.52 \\ (20.55)\end{array} & \begin{array}{l}30.83 \\ (22.61)\end{array} & -5.72 \\ \text { \% small manufacturing establishments, } 1992 & \begin{array}{l}62.25 \\ (21.89)\end{array} & \begin{array}{l}65.10 \\ (26.24)\end{array} & 3.99 \\ \text { \% local/old/small manufacturing, 1992 } & -\mathrm{ND} & +\mathrm{ND} & \mathrm{NS}^{\mathrm{d}} \\ \text { High \% civic denominations, 1990 } & .44 & .40 & -3.05 \\ & (15.01) & (15.88) & \\ \text { High \% family farms, 1992 } & .36 & .36 & -.69 \\ & (.48) & (.48) & \\ \text { Ln third place establishments, } 1992 & +\mathrm{ND} & -\mathrm{ND} & \mathrm{S} \\ \text { Ln associations, } 1992 & +\mathrm{ND} & -\mathrm{ND} & \mathrm{S}\end{array}$

Note: Standard deviations in parentheses.

${ }^{a}$ NA: $t$-ratio not applicable

${ }^{\mathrm{b}}$ ND: Data item not disclosable because of small sample size; + indicates higher value, - lower value.

${ }^{\mathrm{C}} \mathrm{S}$ : $t$-ratio not disclosable; mean difference is significant: $\mathrm{p}<.05(t>1.65)$

${ }^{\mathrm{d}} \mathrm{NS}$ : $t$-ratio not disclosable; mean difference is not significant: $\mathrm{p}>.05(t<1.65)$ 
Table 2. Modeling Civic Community: OLS Regression Results for Median Income and Poverty Rate

\begin{tabular}{|c|c|c|c|c|}
\hline \multirow[b]{2}{*}{ Variable } & \multicolumn{2}{|c|}{$\underline{\text { Ln Median Income }}$} & \multicolumn{2}{|c|}{ Poverty Rate } \\
\hline & Nonmetro & Metro & Nonmetro & Metro \\
\hline CONTROL ITEMS & & & & \\
\hline Intercept & $8.7796 *$ & $8.4981 *$ & $82.3971 *$ & $54.7084 *$ \\
\hline \% high school graduates, 1990 & $\begin{array}{l}.0144 * \\
(.6987)\end{array}$ & $\begin{array}{l}.0180 * \\
(.6005)\end{array}$ & $\begin{array}{l}-.4288 * \\
(-.4836)\end{array}$ & $\begin{array}{l}-.4091 * \\
(-.6031)\end{array}$ \\
\hline Age of housing stock, 1990 & $\begin{array}{l}-.0016 * \\
(-.0736)\end{array}$ & $\begin{array}{l}-.0007 \\
(-.0226)\end{array}$ & $\begin{array}{l}-.0334 \\
(-.0355)\end{array}$ & $\begin{array}{l}.0184 \\
(.0264)\end{array}$ \\
\hline \% Owner occupied dwellings, 1990 & $\begin{array}{l}.0057 * \\
(.2153)\end{array}$ & $\begin{array}{l}.0074^{*} \\
(.2665)\end{array}$ & $\begin{array}{l}-.4789 * \\
(-.4202)\end{array}$ & $\begin{array}{l}-.1521 * \\
(-.2428)\end{array}$ \\
\hline$\%$ Housing vacant, 1990 & $\begin{array}{l}-.0022 * \\
(-.0623)\end{array}$ & $\begin{array}{l}-.0035^{*} \\
(-.689)\end{array}$ & $\begin{array}{l}.0910^{*} \\
(.0590)\end{array}$ & $\begin{array}{l}.1062 * \\
(.0918)\end{array}$ \\
\hline$\%$ Housing occupied $10+$ years, 1990 & $\begin{array}{l}-.0018 * \\
(-.0663)\end{array}$ & $\begin{array}{l}.0003 \\
(.0078)\end{array}$ & $\begin{array}{l}.1889 * \\
(.1589)\end{array}$ & $\begin{array}{l}.0391 * \\
(.0522)\end{array}$ \\
\hline Ln manufacturing establishments, 1992 & $\begin{array}{l}.0156^{*} \\
(.0585)\end{array}$ & $\begin{array}{l}.0035 \\
(.0098)\end{array}$ & $\begin{array}{l}-1.4374 * \\
(-.1257)\end{array}$ & $\begin{array}{l}-.9801 * \\
(-.1205)\end{array}$ \\
\hline$\%$ of urban population in county, 1990 & $\begin{array}{l}-.0501 * \\
(-.0809)\end{array}$ & $\begin{array}{l}-.1411 * \\
(-.0837)\end{array}$ & $\begin{array}{l}2.2369 * \\
(.0839)\end{array}$ & $\begin{array}{l}2.1670 * \\
(.0569)\end{array}$ \\
\hline Adjacent to metro county, 1990 & $\begin{array}{l}.0309 * \\
(.0720)\end{array}$ & ----- & $\begin{array}{l}-.9210^{*} \\
(-.0498)\end{array}$ & ----- \\
\hline Relative populations size, 1990 & $\begin{array}{l}-.0175^{*} \\
(-.0512)\end{array}$ & $\begin{array}{l}-.0001 * \\
(-.0232)\end{array}$ & $\begin{array}{l}3.4128 * \\
(.2321)\end{array}$ & $\begin{array}{l}-.9848 * \\
(.0675)\end{array}$ \\
\hline Northeast & $\begin{array}{l}.1028 * \\
(.1235)\end{array}$ & $\begin{array}{l}.0797 * \\
(.0922)\end{array}$ & $\begin{array}{l}-2.3746 * \\
(-.0663)\end{array}$ & $\begin{array}{l}-3.1006 * \\
(-.1591)\end{array}$ \\
\hline Midwest & $\begin{array}{l}.0287 * \\
(.0639)\end{array}$ & $\begin{array}{l}-.0283 \\
(-.0356)\end{array}$ & $\begin{array}{l}-.4415 \\
(-.0228)\end{array}$ & $\begin{array}{l}-1.813^{*} \\
(-.1008)\end{array}$ \\
\hline South & $\begin{array}{l}.0394 * \\
(.0915)\end{array}$ & $\begin{array}{l}-.0243 \\
(-.0294)\end{array}$ & $\begin{array}{l}1.6089 * \\
(.0868)\end{array}$ & $\begin{array}{l}-.8874 * \\
(-.0475)\end{array}$ \\
\hline $\begin{array}{l}\text { CIVIC COMMUNITY ITEMS } \\
\text { Ln nonemployers, } 1992\end{array}$ & $\begin{array}{l}.0133 * \\
(.0432)\end{array}$ & $\begin{array}{l}.0433^{*} \\
(.1158)\end{array}$ & $\begin{array}{l}-1.5557 * \\
(-.1171)\end{array}$ & $\begin{array}{l}-.0719 \\
(-.0085)\end{array}$ \\
\hline \% local manufacturing establishments, 1992 & $\begin{array}{l}-.0004 * \\
(\mathrm{ND})\end{array}$ & $\begin{array}{l}.0433^{*} \\
(\mathrm{ND})\end{array}$ & $\begin{array}{l}.0119 \\
(\mathrm{ND})\end{array}$ & $\begin{array}{l}-.0055 \\
(\mathrm{ND})\end{array}$ \\
\hline$\%$ old manufacturing establishments, 1992 & $\begin{array}{l}.0004 * \\
(.0396)\end{array}$ & $\begin{array}{l}-.0006^{*} \\
(.0348)\end{array}$ & $\begin{array}{l}-.0073 \\
(-.0163)\end{array}$ & $\begin{array}{l}-.0212 * \\
(-.0564)\end{array}$ \\
\hline$\%$ small manufacturing establishments, 1992 & $\begin{array}{l}-.0004 * \\
(-.0378)\end{array}$ & $\begin{array}{l}.0004 \\
(.0260)\end{array}$ & $\begin{array}{l}.0355^{*} \\
(.0845)\end{array}$ & $\begin{array}{l}.0068 \\
(.0210)\end{array}$ \\
\hline \% local/old/small manufacturing, 1992 & $\begin{array}{l}-.0040 \\
(\mathrm{ND})\end{array}$ & $\begin{array}{l}.1162^{*} \\
\text { (ND) }\end{array}$ & $\begin{array}{l}-1.2097 \\
(\mathrm{ND})\end{array}$ & $\begin{array}{l}.3026 \\
(\mathrm{ND})\end{array}$ \\
\hline High \% civic denominations, 1990 & $\begin{array}{l}.0204 * \\
(.0474)\end{array}$ & $\begin{array}{l}.0093 \\
(.0120)\end{array}$ & $\begin{array}{l}-1.4505 * \\
(-.0783)\end{array}$ & $\begin{array}{l}-.6167 * \\
(-.0355)\end{array}$ \\
\hline
\end{tabular}




\begin{tabular}{|c|c|c|c|c|}
\hline High \% family farms, 1992 & $\begin{array}{l}-.0004 \\
(-.0008)\end{array}$ & $\begin{array}{l}-.0667 * \\
(-.0847)\end{array}$ & $\begin{array}{l}-.9198 * \\
(-.0482)\end{array}$ & $\begin{array}{l}.2707 \\
(.0153)\end{array}$ \\
\hline Ln third place establishments, 1992 & $\begin{array}{l}.0311 * \\
(\mathrm{ND})\end{array}$ & $\begin{array}{l}.0151^{*} \\
(\mathrm{ND})\end{array}$ & $\begin{array}{l}-1.4942 * \\
\text { (ND) }\end{array}$ & $\begin{array}{l}-1.0340 * \\
(\mathrm{ND})\end{array}$ \\
\hline Ln associations, 1992 & $\begin{array}{l}-.0003 \\
\text { (ND) }\end{array}$ & $\begin{array}{l}-.0359 * \\
\text { (ND) }\end{array}$ & $\begin{array}{l}-.3023 \\
\text { (ND) }\end{array}$ & $\begin{array}{l}1.2221 * \\
(\mathrm{ND})\end{array}$ \\
\hline & 6080 & .7042 & 6419 & .6343 \\
\hline
\end{tabular}

NOTES: $* \mathrm{p}<.05$ (one-tailed test such that $t>1.65$ ); Standardized coefficients in parentheses; ND indicates that coefficient is not disclosable because its mean and standard deviation are not disclosed (see Table 1). 
Table 3. Modeling Civic Community: OLS Regression Results for Nonmigration and Unemployment

\begin{tabular}{|c|c|c|c|c|}
\hline \multirow{2}{*}{ Variable } & \multicolumn{2}{|c|}{ Nonmigration } & \multicolumn{2}{|c|}{ Unemployment } \\
\hline & Nonmetro & Metro & Nonmetro & Metro \\
\hline$\overline{\text { CONTROL ITEMS }}$ & & & & \\
\hline Intercept & $39.6086^{*}$ & $43.9450 *$ & $27.3933^{*}$ & $23.6210^{*}$ \\
\hline \% high school graduates, 1990 & $\begin{array}{l}-.3264 * \\
(-.3470)\end{array}$ & $\begin{array}{l}-.3022 * \\
(-.3298)\end{array}$ & $\begin{array}{l}-.1381 * \\
(-.4172)\end{array}$ & $\begin{array}{l}-.1746 * \\
(-.6156)\end{array}$ \\
\hline Age of housing stock, 1990 & $\begin{array}{l}.0429 \\
(.0429)\end{array}$ & $\begin{array}{l}.0775^{*} \\
(.0823)\end{array}$ & $\begin{array}{l}.0370^{*} \\
(.1051)\end{array}$ & $\begin{array}{l}.0159 * \\
(.0547)\end{array}$ \\
\hline \% Owner occupied dwellings, 1990 & $\begin{array}{l}.3246^{*} \\
(.2685)\end{array}$ & $\begin{array}{l}.0984 * \\
(.1162)\end{array}$ & $\begin{array}{l}-.1223^{*} \\
(-.2874)\end{array}$ & $\begin{array}{l}-.0273 * \\
(-.1042)\end{array}$ \\
\hline$\%$ Housing vacant, 1990 & $\begin{array}{l}.0853^{*} \\
(.0521)\end{array}$ & $\begin{array}{l}.0369 * \\
(.0236)\end{array}$ & $\begin{array}{l}.0548^{*} \\
(.0952)\end{array}$ & $\begin{array}{l}.0561^{*} \\
(.1158)\end{array}$ \\
\hline$\%$ Housing occupied $10+$ years, 1990 & $\begin{array}{l}.6283^{*} \\
(.4982)\end{array}$ & $\begin{array}{l}.6726^{*} \\
(.6639)\end{array}$ & $\begin{array}{l}.0623^{*} \\
(.1403)\end{array}$ & $\begin{array}{l}.0098 \\
(.0312)\end{array}$ \\
\hline Ln manufacturing establishments, 1992 & $\begin{array}{l}1.0235 * \\
(.0844)\end{array}$ & $\begin{array}{l}.1152 \\
(.0105)\end{array}$ & $\begin{array}{l}-.5010 * \\
(-.1173)\end{array}$ & $\begin{array}{l}-.4919 * \\
(-.1445)\end{array}$ \\
\hline$\%$ of urban population in county, 1990 & $\begin{array}{l}1.2416 * \\
(.0439)\end{array}$ & $\begin{array}{l}4.9497 * \\
(.0963)\end{array}$ & $\begin{array}{l}-.1809 \\
(-.0182)\end{array}$ & $\begin{array}{l}-.2558 \\
(-.0161)\end{array}$ \\
\hline Adjacent to metro county, 1990 & $\begin{array}{l}-.7685^{*} \\
(-.0392)\end{array}$ & ----- & $\begin{array}{l}.0702 \\
(.0102)\end{array}$ & ----- \\
\hline Relative populations size, 1990 & $\begin{array}{l}1.3936 * \\
(.0893)\end{array}$ & $\begin{array}{l}1.2859 \\
(.0107)\end{array}$ & $\begin{array}{l}1.2828 * \\
(.2336)\end{array}$ & $\begin{array}{l}.6969 * \\
(.1142)\end{array}$ \\
\hline Northeast & $\begin{array}{l}.5184 \\
(.0136)\end{array}$ & $\begin{array}{l}1.2859 * \\
(.0633)\end{array}$ & $\begin{array}{l}-1.6892 * \\
(-.1263)\end{array}$ & $\begin{array}{l}-1.5733 * \\
(-.1930)\end{array}$ \\
\hline Midwest & $\begin{array}{l}.3867 \\
(.0189)\end{array}$ & $\begin{array}{l}1.2859 * \\
(.0529)\end{array}$ & $\begin{array}{l}-.7839 * \\
(-.1086)\end{array}$ & $\begin{array}{l}-.9096 * \\
(-.1209)\end{array}$ \\
\hline South & $\begin{array}{l}-.8917 \\
(-.0453)\end{array}$ & $\begin{array}{l}-1.9839^{*} \\
(.0786)\end{array}$ & $\begin{array}{l}-1.5024 * \\
(-.2169)\end{array}$ & $\begin{array}{l}-1.8257^{*} \\
(-.2335)\end{array}$ \\
\hline $\begin{array}{l}\text { CIVIC COMMUNITY ITEMS } \\
\text { Ln nonemployers, } 1992\end{array}$ & $\begin{array}{l}-.8547 * \\
(-.0607)\end{array}$ & $\begin{array}{l}1.2187 * \\
(.1070)\end{array}$ & $\begin{array}{l}-.6578 * \\
(-.1326)\end{array}$ & $\begin{array}{l}-.2558 * \\
(-.0726)\end{array}$ \\
\hline \% local manufacturing establishments, 1992 & $\begin{array}{l}.0007 \\
(\mathrm{ND})\end{array}$ & $\begin{array}{l}-.0026 \\
\text { (ND) }\end{array}$ & $\begin{array}{l}-.0027 \\
\text { (ND) }\end{array}$ & $\begin{array}{l}-.0045 \\
\text { (ND) }\end{array}$ \\
\hline$\%$ old manufacturing establishments, 1992 & $\begin{array}{l}.0297 * \\
(.0625)\end{array}$ & $\begin{array}{l}.0065 \\
(.0128)\end{array}$ & $\begin{array}{l}-.0062 \\
(-.0369)\end{array}$ & $\begin{array}{l}-.0039 \\
(-.0249)\end{array}$ \\
\hline$\%$ small manufacturing establishments, 1992 & $\begin{array}{l}.0197 * \\
(.0442)\end{array}$ & $\begin{array}{l}-.0082 \\
(-.0188)\end{array}$ & $\begin{array}{l}.0073 \\
(.0468)\end{array}$ & $\begin{array}{l}.0019 \\
(.0141)\end{array}$ \\
\hline$\%$ local/old/small manufacturing, 1992 & $\begin{array}{l}-1.3434 \\
\text { (ND) }\end{array}$ & $\begin{array}{l}-1.2441 \\
(\mathrm{ND})\end{array}$ & $\begin{array}{l}.0790 \\
\text { (ND) }\end{array}$ & $\begin{array}{l}.1146 \\
\text { (ND) }\end{array}$ \\
\hline High \% civic denominations, 1990 & $\begin{array}{l}-.4980 \\
(-.0246)\end{array}$ & $\begin{array}{l}.6928 * \\
(.0289)\end{array}$ & $\begin{array}{l}-.6276^{*} \\
(-.0880)\end{array}$ & $\begin{array}{l}-.1348 \\
(-.0182)\end{array}$ \\
\hline High \% family farms, 1992 & $\begin{array}{l}.6144^{*} \\
(.0313)\end{array}$ & $\begin{array}{l}-.1458 \\
(-.0062)\end{array}$ & $\begin{array}{l}-1.0746^{*} \\
(-.1554)\end{array}$ & $\begin{array}{l}-.3090^{*} \\
(-.0426)\end{array}$ \\
\hline
\end{tabular}




$\begin{array}{lllll}\text { Ln third place establishments, } 1992 & \begin{array}{l}1.0678^{*} \\ \text { (ND) }\end{array} & \begin{array}{l}.0727 \\ \text { (ND) }\end{array} & \begin{array}{l}-.2863 \\ \text { (ND) }\end{array} & \begin{array}{l}-.1716^{*} \\ \text { (ND) }\end{array} \\ \text { Ln associations, } 1992 & \begin{array}{l}.5479^{*} \\ (\mathrm{ND})\end{array} & \begin{array}{l}.7146^{*} \\ (\mathrm{ND})\end{array} & \begin{array}{l}-.2406^{*} \\ \text { (ND) }\end{array} & \begin{array}{l}.2984^{*} \\ \text { (ND) }\end{array} \\ & .6449 & .7402 & .3364 & .5045\end{array}$

NOTES: $* \mathrm{p}<.05$ (one-tailed test such that $t>1.65$ ); Standardized coefficients in parentheses; ND indicates that coefficient is not disclosable because its mean and standard deviation are not disclosed (see Table 1). 